\title{
Dias en Da Gama, Van Wyk Louw en Camões (her)besoek
}

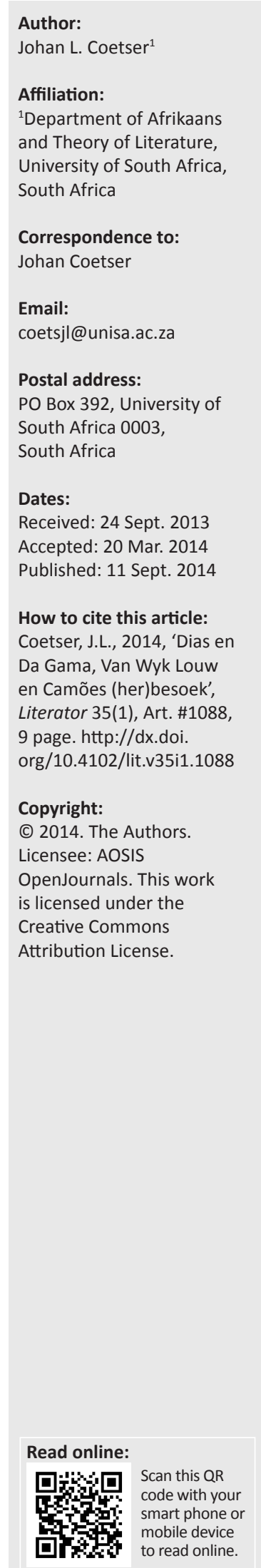

Alhoewel Bartolomeus Dias die eerste Portugese ontdekker was wat om die suidelikste kaap van Afrika geseil het, neem hy in die wêreldgeskiedenis 'n geringe plek in. Sy landgenoot Vasco da Gama het, deur ook om die Kaap te vaar, die eerste seevaarder geword om die Ooste te bereik. Nieteenstaande Dias se geringer prestasie, het N.P. van Wyk Louw verkies om 'n radiodrama oor die gedeelte van Dias se vaart om die Suid-Afrikaanse kus te skryf. Daarteenoor is die geskiedenis van Da Gama se vaart in 'n epiese gedig deur Luís Vaz de Camões opgeteken in sy Os Lusíadas (1572), of Die seuns van Portugal. Die vraag wat ek wil beantwoord, gaan oor die plek en belang wat die dramaturg in Dias (1952) aan temas heg wat teruggevoer kan word tot kanto 5 van Os Lusiadas (1572). Ek neem aan dat die twee tekste met mekaar vergelyk kan word op grond van die teenwoordigheid van die mitiese karakter Adamastor in albei. Soos in Os Lusíadas (1572) neem Adamastor in Dias (1952) die vorm aan van 'n storm. My gevolgtrekking is dat albei tekste, ondanks verskillende oorspronge, 'n allegoriese en 'n nasionale aard vertoon. Die verskillende oorspronge maak dit moontlik om 'n hersiene interpretasie van Dias (1952) te gee.

Dias and Da Gama, Van Wyk Louw and Camões (re)visited. Although he was the first Portuguese explorer who rounded the southernmost cape of Africa, world history does not herald Bartholomew Dias as an important figure. His compatriot Vasco da Gama was the first mariner who reached the Orient by navigating around the Cape. Despite Dias's relative historical unimportance, N.P. van Wyk Louw preferred to write a radio play about him and his journey around the South African coast. Luís Vaz de Camões, on the other hand, wrote an epic poem about da Gama's journey, which he titled Os Lusíadas (1572), or The sons of Portugal. The question I set out to answer, relates to the position and importance that the playwright of Dias (1952) attaches to themes in Canto 5 of Os Lusíadas (1572). I assume that the two can be compared due to the presence of the mythical character Adamastor in both. As in Os Lusiadas (1572), Adamastor takes the form of a storm in Dias (1952). I conclude that, in spite of different origins, both texts are allegorical and national in character. The differences in origin inspired a revised reading of Dias (1952).

\section{Agtergrond}

Ames (2009) beklemtoon die waarde van Da Gama se oopstelling van die seeweg om die suidpunt van Afrika na die Ooste toe in die inleiding tot sy vertaling van Vasco da Gama ${ }^{1}$ se skeepsjoernaal soos volg:

World history for the first time became a reality. In that process there were two seminal voyages which initiated and helped to cement these profound societal links: that of Christopher Columbus from 1492 to 1493 and that of Vasco da Gama from 1497 to 1499. (p. 1)

In teenstelling met sy waardering vir Columbus en Da Gama se prestasies, verwys Ames (2009) opvallend nie na Bartolomeus Dias as Da Gama se voorganger nie. Dias het Lissabon aan die begin van Augustus 1487 verlaat om, soos Da Gama 'n paar jaar later, in opdrag van koning Johan II 'n deurtog om die suidelike punt van Afrika na die ryk markte van die Ooste te vind. Columbus het die seeweg Amerika toe ná Dias se vaart geopen en gevolglik fabelagtige rykdom aan die Spaanse troon besorg. Dat Columbus eers by die Portugese koning om finansiële bystand aangeklop het, maar weggewys is, moes 'n mate van dringendheid aan Da Gama se opdrag verleen het.

Portugese eiename is, so ver as wat prakties moontlik is, verafrikaans. Ek het my in hierdie verband deur die gebruik in vier bronne laat lei. Die bronne is N.P. van Wyk Louw ([1952] 1975) se drama Dias: ' $n$ Hoorspel (hiervandaan aangedui as Dias [1952]), Le Roux en Ferreira [2008:95-110] se inleiding tot en vertaling van 'n gedeelte uit Luís Vaz de Camões [Camoëns 1877] se Os Lusíadas [1572] en De Kock [1957] se Portugese ontdekkers om die Kaap. Waar ek dele van Os Lusíadas [1572] betrek wat nie in Afrikaans in Le Roux en Ferreira [2008:95-110] se vertaling) beskikbaar is nie, maak ek van die Mickle-vertaling van 1776 gebruik (Camoëns 1877). Verder volg ek die gebruik om, in die geval van Van Wyk Louw se Dias (1952) en Camões se Os Lusíadas (1572), in die bespreking die eerste druk van die publikasie ná vermelding van die titel aan te gee. Waar ek uit een van hierdie twee tekste aanhaal, verskaf ek egter, soos met ander verwysings en aanhalings, die jaartal van die uitgawe wat ek gebruik het. Daardeur probeer ek om die historiese plasing van Louw en Camões se tekste te beklemtoon. Verskillende bronne spel Camões se van verskillend. In hierdie bespreking behou ek die spelling van die bron wat ek gebruik het. 
Geplaas naas Columbus en Da Gama se prestasies, en teen die agtergrond van die waarde wat die Westerse geskiedskrywing aan sy vaart heg, verbleek Dias se vaart tot 'n onbenulligheid. Na sy terugkeer in Portugal het geen vergoeding of eerbetoon op hom gewag nie. Al wat van die laaste deel van sy lewe bekend is, is dat hy as die kaptein van 'n skip in Cabral se vloot onderweg na Indië op 20 Mei 1500 in 'n storm omgekom het.

De Kock (1957:112-113) en Welch (1935:198, 219) wys ook op die geringe plek wat Dias se vaart in die geskiedskrywing inneem. Vir Welch (1935:198) lê die verklaring daarvoor in die feit dat Dias se ontdekkingsvaart misluk het en dat die Portugese, bewus van ander moonthede se belangstelling in 'n seeweg na die Ooste ter wille van handelsdoeleindes, 'n sluier van geheimhouding oor hul ontdekkingsvaarte getrek het. Volgens Welch (1935:198) was 'n verdere rede dat veral die ouer Portugese geskiedskrywers Dias en sy vaart geïgnoreer het omdat hy nie van adellike afkoms was nie. Tog was Dias die eerste Europeër wat om die suidpunt van Afrika gevaar het.

Van die passasies in die radiodrama Dias (1952) waaruit die karakter Dias se insig in sy aandeel aan die oopstelling van 'n seeweg na die Ooste toe blyk, weerspieël dieselfde gevolgtrekking as dié waartoe De Kock (1957:112-113) en Welch $(1935: 198,219)$ kom. Dié gedeeltes verteenwoordig 'n terugblik deur die dramaturg as ingeligte organiserende instansie in die teks. Die volgende woorde is 'n voorbeeld: 'Heersend, stil en heerlik/trap bo-oor jou jou eeu [...] Ek het so min verrig/En nou's ek eindelik opsy gelaat/soos skaafsels by die plank' (Louw [1952] 1975:44).

Die geringer plek wat die geskiedskrywing aan Dias se vaart toeken, lei tot die vraag waarom Louw verkies het om 'n radiodrama oor Dias te skryf en nie oor Da Gama nie. Behalwe dat Da Gama 'n volledige dagboek van sy vaart gehou en die dagboek behoue gebly het (vgl. Camoëns [1776] 1877 as een van vele verwerkings van die dagboek, met kommentaar) het Luís Vaz de Camões later 'n lang epos geskryf wat op $\mathrm{Da}$ Gama se vaart gebaseer is. Camões het nie Dias of Da Gama se vaart om die Kaap meegemaak nie en sy Os Lusíadas (1572) is ongeveer 'n driekwart eeu ná Da Gama se vaart na die Ooste toe en terug vir die eerste keer gepubliseer. Die beskikbaarheid van Da Gama se dagboek en Camões se epos sou kon bydra tot Louw se begrip van die historiese en selfs die tydgenootlike, literêre agtergrond van Dias se reis.

Die tweede vraag wat ek met inagneming van hierdie agtergrond wil beantwoord, is wát die belang is wat die dramaturg in Louw se radiodrama Dias (1952) aan temas heg wat teruggevoer kan word na kanto 5 van Luís Vaz de Camões se Os Lusíadas (1572). Twee vrae vloei uit dié hoofvraag voort: eerstens, watter raakpunte is daar moontlik tussen die tekste; en tweedens, tot watter mate is daar met inagneming van moontlike raakpunte sprake van ooreenkomste tussen die tekste?
Dit is nie uit Steyn (1998a, 1998b) se tweedelige biografie oor Louw duidelik of hy Camões se Os Lusíadas (1572) eerstehands geken het nie. Verder kon ek geen bewyse of verwysings na Camões in Louw se werksdokumente, wat in die Dokumentesentrum van die Universiteit Stellenbosch Biblioteek bewaar word, vind nie. Dit is egter moontlik dat Louw indirek met die skeppingsmite van Adamastor in Os Lusíadas (1572) en met hierdie figuur se betrokkenheid by die ontstaan van Tafelberg en die Kaap van Storms bekend was.

Die rede waarom ek Os Lusíadas (1572) as 'n belangrike literêre interteks en as ' $n$ bron van inligting oor Dias (1952) beskou, hou met 'n opvallende ooreenkoms tussen hulle verband. Dié ooreenkoms is dat die mitiese figuur Adamastor 'n bepalende rol in Dias (1952) speel. Camões het hierdie karakter egter eers in sy Os Lusíadas (1572) geskep. Verder gee Louw in Dias (1952) sy interpretasie van die Suid-Afrikaanse gedeelte van Dias se reis, terwyl kanto 5 in Os Lusíadas (1572) Camões se weergawe en interpretasie verteenwoordig van Da Gama se seereis om die Kaap.

Die moontlikheid dat Louw op indirekte wyse van Adamastor bewus was, blyk uit gesprekke tussen Louw en Opperman oor Dias vóór Louw met die skryf van Dias (1952) begin het (Steyn 1998a:517-519)2. Reeds in 1949 het 'n gesprek tussen Louw en Opperman plaasgevind waartydens dit aan die lig gekom het dat al twee iets oor Dias wou skryf. Louw se belangstelling in Dias blyk verder uit 'n vakansie later in dieselfde jaar by Boesmansriviermond en ' $n$ besoek wat hy tydens dié vakansie aan die Dias-kruis gebring het. Die laaste aanleiding was 'n uitnodiging van Douglas Fuchs, streeksdirekteur van die Suid-Afrikaanse Uitsaaikorporasie (SAUK) in Natal, aan Louw om vir die vyf-en-twintigste herdenking van radio in Natal 'n radiodrama oor Vasco da Gama te skryf. Fuchs het Da Gama voorgestel omdat Da Gama aan Natal sy naam gegee het. Louw het egter verkies om 'n stuk oor Dias (1952) te skryf.

Opperman se belangstelling in Dias het op die publikasie van Joernaal van Jorik (1949) uitgeloop, wat 'n werk is waarvoor Louw besondere waardering gehad het. Al het Louw 'jare aan 'n werk oor Dias gedink' (Steyn 1998a:517), bestaan die moontlikheid dat die gedeeltes in Joernaal van Jorik wat op Adamastor en Tafelberg betrekking het, 'n verdere indirekte invloed op die ontstaan van Louw se Dias (1952) gehad het. Vergelyk as 'n moontlike invloed Opperman (1949:8-9) se vermelding van Dias wat, soos 'baie ander vaarders sedertdien', tydens sy terugtog kyk na die 'horingdier van berg', wat met 'sy kwaai klein ogies loer ... en elke skip/wat hom in hierdie modderstiltes steur' laat 'wegsink tot soutwit bene'. Laasgenoemde sluit by Camões se beskrywing van Adamastor se optrede in Os Lusíadas (1572) aan, waaraan ek verder aan vollediger aandag gee.

Adamastor tree nie as 'n menslike karakter in Louw se Dias (1952) op nie, maar soos in Os Lusíadas (1572) verteenwoordig hy die kontinent en die storm wat Dias-hulle moes trotseer 2.Met erkenning aan een van die onbekende keurders van hierdie artikel wat in sy of haar kommentaar op hierdie verband gewys het. 
en wat hulle om die suidpunt van Afrika gewaai het. Die dramaturg maak in sy beskrywing van die kus en storm van allegorie en personifikasie gebruik, waardeur kus en storm, soos Adamastor, menslike eienskappe kry. 'n Voorbeeld daarvan is wanneer Dias, nadat die storm uitgewoed het, van sy 'harde vyand' sê dat hy, naamlik 'hierdie kus', 'wou wegvlug uit ons worsteling' en dat ' $[h]$ y of ek sal breek' (bl. 18).

Daar is gevolglik in Louw se Dias (1952) van kontekste sprake wat interpretasies van dié radiodrama beïnvloed. Omdat die historiese persoon Dias die eerste Europese seevaarder was wat om die Kaap geseil het, begin ek my bespreking met verwysings na die historiese konteks.

\section{Konteks}

Volgens Welch (1935:210) se Europe's discovery of South Africa het hul vrees vir die onbekende see en kuslyn en hul Ptolemaïese wêreldbeeld die bemanning van Dias se skip, die Sint Christoforus, tot die punt gebring om hom te dwing om om te draai Portugal toe. Die belang van Welch (1935) se boek is dat dit as die hoofbron gedien het vir die historiese besonderhede wat Louw met die skryf van Dias (1952) gebruik het (Schutte 1988:40-41).

Aan die basis van sy besluit om om te draai lê die feit dat Dias en Da Gama as historiese persone teenoorstaande geaardhede gehad het. Louw verwys op bladsy 5 van een van sy werkdokumente ${ }^{3}$ na 'n voorval waartydens Da Gama kokende olie op ondervraagdes uitgegooi het - 'n voorval wat vir die dramaturg sy wreedheid illustreer. Hierdie verwysing verskaf 'n leidraad waarom Louw eerder tot Dias se redelikheid en intellek aangetrokke was as tot Da Gama se daadkrag.

In die drama blyk Dias se intellek en redelikheid daaruit dat hy die bemanning eers oorreed om drie dae verder te vaar, maar daarna toegee dat hy met onwillige matrose nie veel uitgerig sal kry nie. Indien Da Gama by die Chalumna-rivier in Dias se skoene gestaan het, sou hy, volgens Welch (1935:209), die leiers van die verset waarskynlik oorboord gegooi en van die mandaat van die koning gebruik gemaak het om die bemanning te dwing om verder te vaar. Om oorboord gegooi te word, sou vir die bemanning erger gewees het as om met kokende olie bedek te word, omdat hulle geglo het dat hulle dan oor die rand van die aarde sal stort.

Tydens Dias se historiese vaart en in Louw se drama glo die bemanning dat die aarde 'n plat skyf is, 'waaroor die uitspansel soos 'n baldakyn op vier hoekpilare gerus het' (De Kock 1957:21). Van die 'Streek van die Suide', soos daar toe na 'n onbekende Afrika verwys is, het die bygelowige bemanning weinig geweet. Wat van die Streek van die Suide bekend was, het op spekulasie en oorlewering berus wat deur Bybelse interpretasies gevoed is. Daarom kon Smith (2011:116) verklaar: 'From a European perspective southern
Africa was invented before it was discovered'. De Kock (1957) beskryf die Streek van die Suide soos volg:

Hierdie nog onontdekte Suidland - terra australis nondum cognita - was afgeskei van die wêreld van [die Bybelse en daarom bekende] Adam deur die 'Ewenaarsee' en vir die oog onsigbaar. Daar skyn die son met volle krag neer en verwring die lewensvorme. (bl. 22)

Sou 'n skip dit te ver in die onbekende Suidland in waag en oor die rand van die aarde vaar, sal skip en bemanning in die vlamme van die hel verdwyn. Voordat hulle oor die kant vaar, kon hulle deur vreesaanjaende wesens gekonfronteer word. Jaritz (2009) beskryf hulle as:

[f]abulous creatures and savage barbarians [...] from the edges of the world [that] lived far away - at the end of the seas, in the East, in India, Africa and, later, also in the Americas. (p. 21)

Daarvan is die karakter Adamastor in Camões se Os Lusíadas (1572) 'n voorbeeld. ${ }^{4}$

Welch (1935:1) oordeel vanuit 'n kultuurhistoriese hoek gunstiger oor die betekenis van Dias se vaart. Daarby maak hy dit moontlik om deur sy gebruik van die woorde 'history of the epic type' in die volgende aanhaling, 'n verband tussen die werklike historiese vaart en Louw se beskrywing daarvan in epiese vorm te lê. Welch (1935) verduidelik sy standpunt soos volg:

In so far as South African History is an expansion of European life and culture, it begins with the Portuguese. Because they did not settle permanently at the Cape, it has been rashly inferred that they made no history here. The struggle of medieval Portugal to reach the Cape is not only history, but history of the epic type. (p. 1)

Dias het met sy vaart nie net die seeroete om die Kaap oopgestel na wat later Suid-Afrika sou word nie. Hy het ook die eerste kulturele verbinding, of soos Welch (1935:1) dit in die aanhaling stel, 'expansion of European life and culture', tussen Suid-Afrika en Portugal gelêt. Soos uit die volgende afdelings sal blyk, was die eerste kennismaking van Europa met die inheemse mense van suidelike Afrika egter ongunstig en selfs vyandig van aard.

\section{Luís Vaz de Camões se Os Lusíadas (1572)}

Soos ek vroeër in my bespreking uitgewys het, was Camões nie aan boord toe Da Gama tydens sy eerste seevaart tussen 20 November en 22 November 1497 om die Kaap gevaar het nie. Camões se eerste kennismaking met die Kaap was in 1553 toe hy aan boord die São Bento in stormweer op pad Indië toe om die Kaap van Storms gevaar het. Hierdie kennismaking was die gevolg daarvan dat koning Johan II 4.Adamastor ontvang verder aan vollediger aandag.

5.Laasgenoemde geld veral ten opsigte van Suid-Afrikaanse letterkunde in Engels. Smith (2011:133) verduidelik dat: '[i]n both Afrikaner history and world-view the attractions and ancestral connections of the culture's European [Portuguese] origins attractions and ancestral connections of the culture's European [Portuguese] origin had sunk below its conceptual horizons by the end of the eighteenth century, and would be ousted from Afrikan r symbolo of Slagtersnek (1815), Great Trek (1836-8), Anglo-Boer War (1899-1902), the recognition of the Afrikaans language and, of course, the temporary triumph of its racist ideologies'. 
hom van vervolging in Portugal vrygestel het ná 'n lewe wat gewissel het van dié van 'n howeling tot 'n straatboef, tronkvoël en soldaat. Die koning se vrystelling was op voorwaarde dat hy militêre diens in die Ooste moet verrig.

In Camões se weergawe van Da Gama se vaart om die Kaap steek 'n stormwolk op wanneer hulle die Kaap nader (kanto 5, stansa 37). Camões beskryf Da Gama en die matrose se reaksie daarop met behulp van personifikasie en in terme van hul Middeleeuse wêreldbeeld:

En ons harte het met onverbloemde vrees gepaar:

Die donker see het diep gebulder en veraf het sy gang

Geraas, asof dit sinloos vasslaan teen 'n rotsrif daar. (Le Roux \&

Ferreira 2008:102)

Die gebruik van personifikasie lei daartoe dat die storm 'n onheilspellende, menslike wese word wat die matrose met 'n gruwelike stemtoon en gekras aanspreek. Die aankondiging van die wese in die storm en sy voorkoms is ewe vreesaanjaend (stansa 39). Hy noem hul 'vervloektes' en veroordeel hul 'tartende houding' (stansa 42) omdat die vloot dit durf waag om in die gebied te vaar waar hy wag hou. Dias ('die eerste vloot', stansa 43) het dit voor hulle gewaag om rondom die Kaap te vaar en dit het hom in 1500 sy lewe gekos toe hy vir die tweede keer as deel van Cabral se vloot suid om die Kaap van Storms wou vaar.

De Kock (1957) skryf dat die 'loeiende suidoosterwind' vir Camões later die:

[...] tartende [...] stem geword [het] van die grusame Adamastor wat uit die wolke wraak teen Da Gama gebulder het, die gryse reus wat as straf vir sy rebellie teen Olimpus in die skurwe berge van die Kaap verander is om as wagter almal voor te keer en die dood te bring aan die seuns van Lusus [die Portugese] wat hom wou omseil. (bl. 140)

Soos De Kock (1957:140) in die vorige aanhaling, beskryf Gray (1979:25) die reus Adamastor in die volgende aanhaling as 'n allegoriese en antropomorfiese voorstelling van Tafelberg en die Kaap van Storms. Soos later uit hierdie bespreking sal blyk, maak ook Louw in sy radiodrama van allegorie as werkwyse gebruik. Gray (1979) skryf:

He [Camões] knows that his readers will see Table Mountain as a rocky forehead, and the caps of waves as moaning grey moustaches over hollow mouths. He knows that whirlpools will appear as sunken eyes, and that when the black maw of the sea pulls back over reefs, his audience will expect the yellow teeth. Those are the awe-inspiring details by which the tempestuous Cape is anthropomorphized into a giant. (p. 25)

Op Da Gama se vraag wie hy is (stansa 49), bevestig die reus dat hy 'daardie verborge en grootse Kaap' is (stansa 50) en dat sy naam Adamastor is (stansa 51).

Naas die oortreding van opstand teen die gode, het Adamastor op Thetis, 'die uitnemende eggenote van Peleus' en 'prinses van die branders' (stansa 52), verlief geraak. Hierdie gedeelte van die verhaal skyn outobiografies te wees, vanweë ooreenkomste met Camões se gefnuikte verhouding as jong howeling aan koning Johan II se hof met Doña Caterina de Atayde. Hul verhouding was, weens Doña Caterina se posisie as hofdame in die koningin se huishouding, ten strengste taboe en, soos Thetis vir Adamastor, die begin van Camões se teëspoed wat daarop uitgeloop het dat hy na die Ooste verban is (Camoëns [1776] 1877:ix). Adamastor se straf was dat hy in die rotsmassa verander is wat vandag as Tafelberg bekend staan. Die 'prinses van die branders' (stansa 52) het vir hom onbereikbaar gebly, want sy kon nou slegs in die vorm van golwe om sy voet spoel.

Nadat Da Gama se vloot van Adamastor afskeid geneem het ('Sy storie klaar en met ' $n$ aaklige geween in ons ore/Het hy skielik in die skemer voor ons weggeraak', stansa 60), eindig Camões hierdie gedeelte van sy epos op 'n pessimistiese noot. Soos die dramaturg in Dias (1952) verwys hy na 'n 'donker land'. Hierdie verwysing ontvang verder aan weer aandag:

Ons het begin om stadig langs die kus se wang

Deur die branders oos te sny onder volle seil en vlag,

En na ons verder opgevaar het teen die donker land

Het ons die skip geanker by 'n tweede strand [die huidige Mosselbaai]. (Le Roux \& Ferreira 2008:107)

Camões se dramatiese epos gaan nie net oor Da Gama se vaart nie, maar is ook 'n literêr historiese rekonstruksie van die glorie van Portugal se geskiedenis waarin Da Gama se oopstelling van die seeroete na die Ooste 'n sentrale plek inneem. Na die vloot se vaart om die Kaap het Da Gama se werklike, historiese besoek aan die hawe van Malindi aan die Ooskus van Afrika aan Camões die geleentheid gebied om hoogtepunte uit die Portugese geskiedenis in kanto 3 van sy epos in te werk (vgl. Mickle se vertaling in Camoëns [1776] 1877:60 en verder). Os Lusíadas (1572) vertoon gevolglik 'n soortgelyke struktuur as ' $n$ raamvertelling. Laasgenoemde hou in dat Da Gama in die teks die Portugese nasionale geskiedenis op versoek van die sjeik van Malindi aan hom oorvertel. Daardeur tree Da Gama as Camões se dramatiese alter ego op en vind dié vertelling eintlik vanuit Camões se siening van die geskiedenis plaas.

Let in die volgende aanhaling op die patriotisme wat uit Da Gama se toespraak voor die sjeik blyk. Hy begin sy vertelling soos volg:

When slowly turning with a modest grace,

The noble VASCO rais'd his manly face;

O mighty king (he cries), at thy command

The martial story of my native land

I tell; [...]

Though day would sail a narrative so long,

Yet, well assur'd no fiction's glare can raise,

Or give my country's fame a brighter praise; (Camoëns [1776] 1877:61)

Camões se patriotisme blyk die duidelikste uit sy beskrywing van die sjeik en sy onderdane se reaksie op Da Gama se toespraak. Sy nasionalistiese instelling tree in die hiperboliese aard van die beskrywing na vore:

The king, enraptur'd, own'd the glorious fame Of Lisbon's monarchs and the Lusian name; What warlike rage the victor-kings inspir'd! 
Nor less their warriors' loyal faith admir'd.

Nor less his menial train, in wonder lost,

Repeat the gallant deeds that please them most, (Camoëns [1776] 1877:161)

Camões se literêre nalatenskap en die neerslag van nasionalisme daarin is kwalik van mekaar te skei. Dit is soortgelyk aan die nasionalisme wat in Dias (1952) voorkom (vgl. die bespreking in die volgende afdeling). Daarom verwys Gray (1980:2), in 'n herdenkingslesing tydens die viering van Portugal se nasionale dag, na Camões as 'the figurehead and emblem of the Portuguese national spirit'. Hierdie literêre nalatenskap is deur sy opleiding gevorm. In die volgende paragrawe lig ek slegs daardie aspekte van sy opleiding uit wat vir hierdie betoog ter sake is. ${ }^{6}$

As jong man het Camõens sy opleiding in die klassieke Griekse mitologie en letterkunde aan die Universiteit van Coimbra ontvang. Met dié opleiding as agtergrond tree sy kennis van die klassieke in Os Lusíadas (1572) na vore in die gebruik van figure uit die Griekse mitologie. Dit sluit onder andere Bacchus en Venus (Camoëns [1776] 1877:20, 40 en verder) in. Camõens se kennis van die klassieke moes 'n rol gespeel het in sy skepping van die figuur van Adamastor, wat al as die laaste mitiese figuur beskryf is wat in die klassieke letterkunde geskep is (Le Roux \& Ferreira 2008:100). Daarby bied Camõens die verhaal van Os Lusíadas (1572) as 'n reis in die vorm van fiksionele historiografie aan. Juis die optrede van figure uit die Griekse mitologie beklemtoon die fiksionele aard van die verhaal. Die historiografiese aard daarvan vul die fiksionele aard aan omdat Camõens sy werk op Da Gama se historiese reis na die Ooste baseer.

Die optrede van figure uit die mitologie, die skepping van die mitiese karakter Adamastor en die voorstelling van Da Gama se reis in die vorm van 'n fiksionele historiografie maak dit moontlik om Os Lusíadas (1572) met klassieke reis-eposse, soos Homeros se Ilias en Odusseia, te assosieer. Mickle (Camoëns [1776] 1877:xxv-xxxiii) onderskryf dié afleiding in sy 'Dissertation on The Lusiad, and on epic poetry' wat sy vertaling van Os Lusíadas (1572) voorafgaan. Hiermee kom Fletcher (1982:151) se standpunt ter sprake dat dit in allegoriese lesings van eposse soos Homeros se Ilias en Odusseia gaan oor simboliese optredes wat geïnterpreteer kan word as 'progresses and battles' en dat 'fictions of this type necessarily have double meanings'.

Die bespreking en interpretasie van raakpunte tussen Os Lusiadas (1572) en Dias (1952) in hierdie afdeling van my bespreking, dit wil sê die 'double meanings' waarna Fletcher (1982:151) in die vorige aanhaling verwys, kom daarop neer dat 'n allegoriese lesing van Dias (1952) moontlik is. Ek het met die woord 'raakpunte' die verwysings wat ek vroeër na die matrose se wêreldbeeld, die voorstelling van die mitiese figuur Adamastor as Tafelberg en Adamastor se verskyning in die storm, die vermelding van 'n 'donker land', die nasionalisme wat uit Camõens se werk spreek en die allegoriese aard van Os Lusíadas (1572) in gedagte. Laasgenoemde kom daarop neer dat Camõens se Os Lusíadas (1572) in 'n allegoriese sin as 'n 'voorteks' vir Louw se Dias (1952) gedien het. ${ }^{7}$ My verwysings na Steyn en Opperman in my agtergrondbespreking aan die begin van die artikel dien as aanleiding tot dié stelling.

Die voorafgaande bespreking open die moontlikheid dat minstens twee belangrike raakpunte tussen Louw se Dias (1952) en Camões se Os Lusíadas (1572) voorkom. Dit is hul allegoriese aard en die inkleding wat beide skrywers aan die nasionale aspek in hul werke gee. Ander raakpunte waarna ek vroeër verwys het, hou direk of indirek met hierdie twee temas verband. Dié twee temas ontvang vervolgens aandag.

\section{N.P. van Wyk Louw se Dias: 'n Hoorspel (1952)}

In Dias (1952) dien die interpretasie dat die handelingsverloop as die representasie van 'n lewensreis beskou kan word, as 'n aanduiding van die teks se allegoriese aard. Dié interpretasie word aangevul deur die matrose se reaksie op hul oortuiging dat hulle die rand van die aarde bereik het. Hul vrese is ook Dias se vrese, waardeur hulle, volgens Antonissen (1973:250), projeksies van die menslike siel en daarom van Dias self word.

\section{Allegoriese aard}

Die Aankondiger gee in die neweteks voor die aanvang van die eerste deel 'n aanduiding daarvan dat die handelingsverloop allegories is. Dié allegoriese aard blyk daaruit dat die Aankondiger Dias se naam, die naam van sy skip en die verklaring van laasgenoemde in die personelys met mekaar in verband bring. Die volgende aanhaling gee 'n aanduiding daarvan dat, soos Fletcher (1982:151) in verband met allegorieë skryf: 'fictions of this type necessarily have double meanings'. In die aanhaling word Christoforus, die beskermheilige van reisigers wat volgens oorlewering die Christus-kind oor 'n vol rivier gedra het, die ekwivalent van Dias se vlagskip, die Sint Christoforus. Daarmee word die allegoriese reismotief in die vorm van 'n personifikasieallegorie in Louw ([1952] 1975) se teks bekendgestel:

Bartolomeus Dias: Op die skip wat die naam Sint Christoforus dra: 'n herinnering aan die Heilige Christoforus uit ' $n$ ou verhaal, wat die Christus-kind oor die water van 'n stroom gedra het. (bl. 3-4)

7.Ek volg in my toepassing op Van Wyk Louw se Dias (1952) Fletcher (1982) se beskouing van die allegorie as 'n simboliese modus. Fletcher (1982:2) interpreteer die woorde 'symbolic mode' in die subtitel van sy boek breedweg as 'iets' wat vir 'iets' anders staan, dit wil sê die teenwoordigheid van 'double meanings' waarna ek in 'n vorige paragraaf verwys (Fletcher 1982:151). Laasgenoemde moet, in die ek in 'n vorige paragraaf verwys (Fletcher 1982:151). Laasgenoemde moet, in die lig van Malan (2010) se opmerking dat die allegorie 'n narratiewe tegniek is, gelees word. Daarom sal dit ongegrond wees om ' $n$ vaste betekenis aan ' $n$ allegorie toe te 'kwaad' gaan. Die allegoriese word nie 'deur die kritiese interpretasie bybetrek nie, maar is deel van die struktuur van die werk' (Malan 2010). Verskillende vorme van beeldspraak kan in 'n allegorie voorkom, waarvan personifikasie die omvattendste in ' $n$ personifikasie-allegorie is (vergelyk my verwysings na Dias se skip, die Sint Christoforus, in die volgende afdeling van hierdie artikel). Nog ' $n$ vorm van allegorie wat vir hierdie bespreking ter sake is is wat ek 'n parallelle allegorie noem (Coetse 1986:37-38). Honig (1982:24) gee die volgende beskrywing daarvan: 'We find the 1986:37-38). Honig (1982:24) gee die volgende beskrywing daarvan: 'We find the allegorical quality in a twice-told tale written in rhetorical, or figurative language and expressing a vital belief. The twice-told aspect of the tale indicates that some venerated or proverbial antecedent (old) story [in hierdie geval Camõens se Os Lusiadas, 1572] has become a pattern for another (the new) story [Van Wyk Louw se Dias, 1952]'. In Camõens en Louw se verhale word hul gemeenskaplike 'twice-told tale' (vorige aanhaling) deur raakpunte tussen hulle met mekaar verbind, waarvan die teenwoordigheid van Adamastor die belangrikste is. 
Die teks gee daarvan aanduidings dat 'n volledige lewensverloop met 'n dubbele betekenis betrokke is. Die titelkarakter verduidelik byvoorbeeld aan Pedro op bladsy nege dat hy 'die groot en somber Prins' (prins Hendrik die Seevaarder) jare gelede, 'toe ek [Dias] 'n kind was, self [in die hawe van Sagres] gesien' het. Hy is ook 'uit 'n geslag van seevaarders gebore', maar het 'jare lank [as] hawemeester in Lissabon' gewerk totdat koning Johan II aan hom die opdrag gegee het om die deurtog na die Ooste te vind en om 'n verbond met Priesterkoning Jan, 'wat êrens in Ethiopië moet heers', te sluit (bl. 3). Hy keer aan die einde van die vyfde deel na Portugal terug en sterf twaalf jaar later in 'n storm waarvan die luisteraar in deel 6 verneem.

Le Roux en Ferreira (2008:108) wys daarop dat die naam Adam in die naam Adamastor voorkom. Met die verhaal van die Bybelse Adam as voorteks (kyk voetnoot 7 van hierdie artikel) verleen hierdie raakpunt aan Adamastor se opstand teen die gode in Os Lusíadas (1572, stansa 51) 'n klassiek tragiese én Christelik tipologiese betekenis. Le Roux en Ferreira (2008:108, voetnoot 13) verstrek ook ander etimologiese verklarings vir die naam, waarvan nie een so nou by die argument in hierdie artikel aansluit as die Christelik tipologiese verklaring wat uit die reismotief in Dias (1952) spreek nie.

As ontdekkingsreisiger groei Dias van 'oormoed tot ootmoed'. In hierdie opsig vertoon sy lewensloop raakpunte met dié van elke mens. Antonissen (1963) sluit by hierdie siening aan:

So vorm 'n mens se groei van oormoed tot ootmoed die ryke kern van hierdie melodrama. Dias is die geval van 'n mens, deur God gebrei, gebreek, gesuiwer: die geval van elke mens. (bl. 12; my kursivering)

Aan die begin van hul vaart wil Dias van Pedro weet: 'Was ooit 'n vaarder nog in so 'n nag?' (bl. 5). Hy moedig Pedro aan om vinniger te vaar, want hul skip, die Sint Christoforus, móét vinniger vaar as die ander skip in die vloot, die San Pantaleão (bl. 5). Dié voortvarendheid staan in teenstelling met die gebrokenheid wat aan die einde van die vierde deel uit Pedro se woorde spreek wanneer hy na Dias verwys. Die skepe draai om om na Portugal terug te keer:

Dias: Niks sal my naam dra nie. Want ek was niks.

Ons sal hom na die storms noem. Of na die hoop ${ }^{8}$

Van die wat ná ons kom. [...]

Pedro: Dat ons hom só laat gaan:

Hy huil soos iemand wat' $n$ kind moet groet

in 'n vreemde land, vir nooit weer sien nie. (bl. 40)

Pedro se woorde is in vertaalde vorm uit Welch (1935) se Europe's discovery of South Africa geneem, waardeur die invloed van hierdie bronteks weer eens beklemtoon word. Pedro se woorde lui in Welch (1935) soos volg:

[...] when they paid the return visit to the furthermost pillar which Dias had erected in honour of St. Gregory, and when they were about to sail away, he displayed the grief of a father in leaving a son in lonely exile. (p. 211)

8.Die woorde 'storms' en 'hoop' verwys na name van dieselfde kaap, naamlik die Kaap van Storms of die Kaap van Goeie Hoop.
Verder is daar, naas ' $n$ allegoriese interpretasie van Dias se lewensreis, reeds in Camões se representasie van die storm in Os Lusíadas (1572) sprake van mitologisering en allegorisering (Gray 1979:15; Fletcher 1982:151).

Adamastor is immers 'n natuurverskynsel, 'n storm, wat op menslike wyse met Da Gama in gesprek tree. In teenstelling daarmee sluit die matrose se belewing van die storm in Dias (1952) dus in hul kennismaking met Adamastor, op allegoriese wyse, aan by hul Ptolemaïese wêreldbeeld. Vir hulle word die storm ' $n$ lewende wese, en daarom een van die lewende wesens in die vorm van 'n fabelagtige kreatuur ('fabulous creatures'; Jaritz 2009:21) wat, soos die siening van die matrose was, op die rand van 'n plat aarde woon.

Teen die einde van die reis, te midde van 'n storm, begin die matrose muit omdat hulle daarvan oortuig is dat hulle die rand van die plat aarde nader. Eerste Matroos praat namens die hele bemanning wanneer hy sê: 'Ons wil nie sterf:/ sterwe, en sterf in sonde, ewig sterwe/' (bl. 15). In teenstelling daarmee verklaar Tweede Matroos dat hulle wel sal sterwe, want dit is nie God se wil dat hulle die see van die Suidelike Streek moet bevaar nie (bl. 13). Eerste Matroos is so oortuig van hul standpunt, dat hy, volkome irrasioneel, reeds die vuurkole van die hel onder die water kan waarneem (bl. 13): 'Hierdie water is gruwelik: swart en deurskyn/na onder asof daar iets onder gloei'.

\section{Nasionale aard}

Die nasionale aard van Louw se Dias (1952) kan, soos ek inleidend uitgewys het, tot die allegoriese kryg/oorlog of botsing in werke wat allegories van aard is, teruggevoer word (Fletcher 1982:151, soos vroeër aangehaal). Veral ter sprake is kanto 3 van Camões se Os Lusíadas (vgl. Mickle se vertaling in Camoëns [1776] 1877:60 en verder). Camões lei Da Gama se vertelling van die Portugese geskiedenis aan die sjeik van Malindi met 'n spesifieke militêre verwysing in, naamlik: 'The martial story of my native land/I tell' (ibid:61). Sy vertelling sluit ' $n$ groot getal verwysings na veldslae en oorloë in, onder andere die Slag van Ourique (bl. 71-75), Alphonso se oorlog teen die Leonese (bl. 79-80) en Don Sancho se beleg van Sylves (bl. 84).

In teenstelling daarmee gee die dramaturg in Louw se drama geen verslag van gewelddadige botsings met die inwoners van die kusgebied waarlangs Dias geseil het nie. Hy gee selfs geen weergawe van plekke waar die vloot onvermydelik vars water móés inneem nie, al verklaar die Aankondiger aan die begin van die tweede deel: 'Die twee skepe kon met moeite bymekaar bly; die kos en water het min geword' (bl. 11). Aan die begin van deel 4 staan dat 'Johan Infante die eerste aan wal gegaan [het] met 'n paar manne' (bl. 35). Al het die vloot hier, by die Chalumna-rivier, omgedraai, gee die Aankondiger steeds geen verwysing na die bewoners van dié omgewing nie.

Die luisteraar kan daaruit aflei dat die dramaturg se nasionale perspektief op die geskiedenis verskil van die nasionale 
aard wat spreek uit Camões se weergawe by monde van Da Gama aan die sjeik van Malindi. Nieteenstaande dié verskil is 'n vergelyking tog moontlik omdat 'n groot deel van Camões se Os Lusíadas (1572) as die skeppingsverhaal van Portugal beskou word, terwyl Louw se Dias (1952) vanuit 'n Portugese (Welch 1935:1) én Suid-Afrikaanse perspektief as die skeppingsverhaal van Suid-Afrika kwalifiseer (Gray 1979:15). Deel van dié Suid-Afrikaanse blik op Suid-Afrika se ontstaansgeskiedenis is dat die Aankondiger vermeld dat Dias ses klipkruise aan boord gehad het (bl.3). Die dramaturg se Suid-Afrikaanse perspektief blyk daaruit dat hy net die name van die twee kruise noem wat op Suid-Afrikaanse grond geplant is. Die St. Gregorius is by die omdraaipunt by die Chalumna-rivier geplant (bl. 40; Welch 1935:211), terwyl dit slegs uit historiese bronne bekend is dat die St. Filippus tydens die terugreis êrens in die Kaapse skiereiland opgerig is (Welch 1935:214).

Die dramaturg gee reeds vroeg in Dias (1952) blyke van die teenoormekaarstelling van Portugal (Europa) en SuidAfrika as plekke en identiteitsruimtes soos dit met sy SuidAfrikaanse perspektief verband hou. Dias en Pedro gaan aan die begin van die veronderstelling uit dat hulle aan die einde van die reis na Portugal sal terugkeer. Dit is opmerklik dat Pedro die tuiskoms eerste noem: 'En, Dias, as ons kom,/ná hierdie tog, in Portugal' (bl. 7). Daaruit blyk by hom 'n sekere verbondenheid aan Portugal, wat nie op daardie oomblik by Dias voorkom nie. Nou reeds het Dias hom losgemaak 'van daardie wêreld/wat húlle ken' (bl. 5), met ander woorde van Europa. Dié losmaking by Dias blyk, onder andere, uit die dramaturg se gebruik van deiktiese woorde, soos 'daardie' en 'húlle' in die vorige aanhaling.

Selfs twaalf jaar later, aan die einde van sy lewe, kyk Dias tydens sy gesprek met Jong Offisier 'uit na die suide' (bl. 41). Soos Dias, aan die begin van sy ontdekkingstog, openbaar Jong Offisier 'n nuwe wêreldbesef, maar sy nuwe wêreld is Suid-Amerika (bl. 43). Dias voel hom egter nie soos Jong Offisier by daardie Nuwe Wêreld betrokke nie, want die geskiedenis het hom onomkeerbaar met Suid-Afrika verbind.

Die dramaturg se voorstelling van wat ek hierbo 'n SuidAfrikaanse perspektief genoem het, is nie ideologies neutraal nie. Van Rensburg (1975:52) verklaar in hierdie verband dat 'die nasionalisme soos 'n son in sy [Louw se] werk aanwesig [is]; dit deurdring alles'. Alhoewel hy nie spesifiek na Louw se Dias (1952) verwys nie, geld Van Rensburg (1975:53) se kensketsing van 'n kulturele nasionalisme ook ten opsigte van hierdie radiodrama. Van Rensburg merk tewens verder aan op dat dié vorm van nasionalisme 'op 'n baie duidelike wyse in sy [Louw se] dramas' na vore tree. Van Rensburg (1975; oorspronklike kursivering) lig sy stelling soos volg toe; my toepassing op Dias (1952) verskyn tussen vierkantige hakkies:

Dis miskien net die hoorspel Lewenslyn wat nie hierdie 'nasionale' inslag of aanslag het nie. In al die ander kry ons ' $n$ individu of individue wat hulle in 'n kontrapuntsposisie [Dias] met betrekking tot hul gemeenskap [die bemanning] bevind, en hierdie gemeenskap is byna sonder uitsondering een wat nasionaal of nasionaal-van-allure is. Dit geld nie alleen die dramas waarin die Afrikanervolk [...] die tema is nie, maar ook dié waarin ander volkere of volksekwivalente aan die orde is, selfs al sou die volk onder ironiese opsig [Da Gama as Camões se alter ego, dit wil sê die karakter Da Gama se perspektief in sy vertelling van die Portugese geskiedenis] betrek wees, soos in Die held. (bl. 65)

Teen die agtergrond van'n een-en-twintigste eeuse herbesoek aan Louw se interpretasie van Dias se historiese vaart rondom die Kaap van Storms, tree die dramaturg se inkleding van die nasionalisme daarin toenemend as 'n weerspreking na vore. Onderliggend aan dié weerspreking is wat Van Rensburg (1975) in die aanhaling 'ander volkere of volksekwivalente' noem wat 'onder ironiese opsig' (oorspronklike kursivering) betrek is.

Die woorde 'onder ironiese opsig' en die periode toe Louw se belangstelling in die historiese figuur van Dias gegroei en op die skryf van 'n radiodrama uitgeloop het, val saam met Louw se beskouing van die nasionalisme wat Degenaar (1976a:23) as 'n 'estetiese nasionalisme' beskryf en wat teen ongeveer 1950 deur 'n 'nasionale liberalisme' opgevolg is (ibid:27). Volgens Degenaar (1976a, 1976b, 1976c) het Louw se siening van nasionalisme in fases verloop, waarvan sy estetiese nasionalisme die eerste was en by hom die oorheersende siening was toe hy Dias (1952) geskryf het. Aan die basis van Degenaar se verklaring vir die aanwesigheid van hierdie vorm van nasionalisme by Louw, is sy interpretasie van die klem wat Louw op die estetiese in die Afrikaanse letterkunde plaas. Volgens Degenaar (1976a) stel Louw met hierdie klem twee standpunte:

[...] die eerste is die legitimering van die partikuliere volksbestaan deur deelname aan ewige skoonheidswaardes d.m.v. die taal, en die tweede is die onderworpenheid van die individu aan die volk. Sy verbinding van die twee gedagtes werk mee aan sy absoluutstelling van die nasionale. (bl. 26)

Juis Louw se 'absoluutstelling van die nasionale' (vgl. bostaande aanhaling) bring mee dat sy estetiese nasionalisme 'n volksnasionalisme word waarin enkelinge wat nie hierdie sieninge deel nie, nie deel van die volk kan wees nie. Daarmee onstaan 'n Ek-Ander-spanning binne Louw se siening van 'n estetiese nasionalisme wat ook in die radiodrama Dias (1952) identifiseerbaar is. Vanuit 'n een-en-twintigste eeuse perspektief lei Louw se siening van estetiese nasionalisme tot die identifisering van weersprekings, of Ek-Anderspannings, in sy radiodrama.

Ek gebruik die woord 'weerspreking(s)' in hierdie bespreking in die betekenis dat Louw in Dias (1952) verkies het om nie verwysings na en voorstellings van die historiese Dias en sy bemanning ('Ek') se soms gewelddadige ontmoetings met die inwoners van die streek ('Ander') in sy drama op te neem nie. Die getal historiese insidente dien as ' $n$ aanduiding daarvan dat hierdie weersprekings in die subteks van Dias (1952) doelbewus is. Laasgenoemde berus daarop dat die dramaturg verkies het om verwysings na en voorstellings van historiese botsings met plaaslike inwoners te ignoreer, waardeur, in vergelyking met die historiese verloop, oop plekke in die handelingsverloop van sy drama ontstaan het. 
My interpretasie van 'weersprekings' in Louw se Dias (1952) sluit by kritici se revisionistiese sienings van sy nasionalisme aan, wat ná Degenaar se artikels verskyn het (vgl. Olivier 1992, 1998; Renders 2002, Cattell 2008). Slegs Renders (2002) skryf uitsluitlik oor Louw se dramas. Olivier (1992:16) is van mening dat Degenaar se 'onderskeid tussen 'n "estetiese" en 'n "etiese" nasionalisme' reg laat geskied 'aan die verskil tussen Louw se politieke denke in die jare dertig en vyftig'. Wat in Olivier $(1992,1998)$ se sienings vir hierdie bespreking van belang is, is die aandag wat hy gee aan begrippare soos 'koloniale' en 'nasionale' letterkunde, 'wil' en 'daad', 'heerser' en 'humanis' of die karakter Dias se aard as oorgangsfiguur binne Louw se oeuvre. As historiese oorgangsfigure het Dias en Da Gama hul reise op die oorgang van die Middeleeue (met 'n gepaardgaande Ptolemaïese wêreldbeeld) na die Renaissance en die Verligting afgelê. Soos ek vroeër uitgewys het, het Dias en sy bemanning se Ptolemaïese wêreldbeeld, soos dit in Louw se drama weerspieël is, 'n deurslaggewende invloed op die radiodrama se handelingsverloop gehad.

Nie net sluit my gebruik van begrippare as werkwyse per se by Louw se werkwyse aan nie. Dié aansluiting geld tot' $n$ mindere of meerdere mate ook van die interpretasie van begrippare (vgl. Cattell 2008:16). Vir die doel van my bespreking is Cattell (2008) se interpretasie van die teenoormekaarstelling van die begrippe 'ideologie' en 'utopie' die belangrikste. Sy verduidelik in navolging van Ricoeur (1986:298) dat mag as die 'kruispunt' tussen ideologie en utopie funksioneer. Sy beskryf die aard van dié 'kruispunt' soos volg:

[...] ideologie legitimeer politieke en sosiale heerskappy, byvoorbeeld, terwyl utopie daardie gesag in twyfel trek. Ideologie ontstaan in die gaping tussen die bewindvoerder se aansprake op regmatigheid en die aanvaarding daarvan deur die burgers (13); die funksie van utopie is om hierdie gaping bloot te lê. (Cattell 2008:5-6)

Cattell (2008) se verduideliking dat 'die funksie van utopie is om hierdiegapingbloottelê' laatdiemoontlikheid oop datdaar in die begrippaar 'ideologie' en 'utopie' van weersprekings sprake kan wees soortgelyk aan die weerspreking inherent aan Louw se voorstelling van 'n estetiese nasionalisme in sy radiodrama Dias (1952). Hierdie weerspreking hou, soos ek vroeër uitgewys het, met die mag van uitsluiting deur die Ek van die Ander uit 'n volksgemeenskap verband, wat weer deur Louw se interpretasie van estetiese nasionalisme gedefinieer word.

'n Eerste weerspreking in Louw se Dias (1952) hou met die historiese feit verband dat Dias tydens die heenreis ses slawe wat voorheen uit Afrika weggevoer is, as tolke en afgesante saamgeneem en aan wal gesit het. Die dramaturg verwys nie in die teks na hulle nie. ' $n$ Slavin uit Guinee is byvoorbeeld by Walvisbaai alleen aan wal geplaas, waarna sy hoogs waarskynlik in die woestyn omgekom het (De Kock 1957:99100; De Vries 1988:7).

'n Verdere weerspreking is die historiese gegewe dat Dias die stadige vragskip (vgl. die Aankondiger se woorde op bl. 4) tussen die Groot-Visbaai en Sint Helenabaai by Port
Alexander met enkele bemanningslede aan boord agtergelaat het (De Kock 1957:102, De Vries 1988:7). Die bedoeling was dat die vragskip tydens die terugvaart by die vloot sou aansluit. Dit het egter nie gebeur nie, soos Welch (1935) die gebeure herkonstrueer wat plaasgevind het nadat Dias-hulle verder suid geseil het:

Seeing the Portuguese in such small force, the Natives had robbed them of all they possessed. In defending themselves six out of the nine Europeans had been killed. Of the remaining three Fernâo Colaço [...] died of heart shock caused by the sudden joy of seeing friends, whom he had never hoped to meet again. The boat had become utterly unseaworthy [...]. (pp. 213-214)

De Vries (1988:8), Welch (1935:207) en De Kock (1957:104, 106) doen van 'n derde weerspreking verslag, waartydens die botsing tussen Dias en sy bemanning en die '[v]reemde land van duin en donker struike' (bl. 21) met lewensverlies gepaard gegaan het. Pedro gebruik hierdie woorde. Sou ons sy voorafgaande spreekbeurt in aanmerking neem, blyk dit dat hy met die woord 'duin' na die land en met die woorde 'donker struike' na die inwoners van die land verwys:

Pedro: Daar's hutte en daar's vee. Ook hierdie aarde het sy mense. [...]

Pedro: 'n Vreemde land van duin en donker struike, swart en wit.

Dias: Waar niemand Christus noem Dít is die land waar ek dalk sal onthou word. (Louw [1952] 1975:21)

In Dias (1952) verwys Pedro se woorde 'swart en wit' in die aanhaling nie in die eerste plek na die rasseteenstellings in die huidige Suid-Afrika nie, maar eerder na die teenstelling tussen Christen en nie-Christen. Dias reageer immers net daarna met die woorde: 'Waar niemand Christus noem' (bl. 21). Verder wys Van Heerden (1978:11) daarop dat 'hierdie kleurwoorde [naamlik'swart' en 'wit'] spesifiek as duiders van rassespanning in ons land minder opvallend' is in Van Wyk Louw se oeuvre.

Die dramaturg verkies om nie in Dias (1952) na die botsing tussen die 'donker struike' (aanhaling bo) en Dias te verwys nie. Dié botsing het, volgens De Kock (1957:104, 106), by die huidige Mosselbaai plaasgevind. Dias-hulle kon nie daar met die 'donker struike' onderhandel nie omdat hulle nie 'n tolk gehad het wat die plaaslike taal verstaan nie. Hulle het Dias se geskenke verwerp en die bosse ingevlug terwyl hulle die Portugese met klippe gegooi het. De Kock (1957:104) verduidelik dat Dias 'toe blykbaar sy geduld verloor [het] en een van die Hottentotte met ' $n$ kruisboog doodgeskiet het'.

Daar bestaan ten opsigte van hierdie voorval 'n raakpunt tussen Louw se Dias (1952) en Camões se Os Lusíadas (1572). Ook Camões vermeld in Le Roux en Ferreira (2008:107) se vertaling dieselfde kuslyn en noem dit 'die donker land'. Soos die historiese Dias (De Kock 1957:104), bots Da Gama-hulle in kanto 5 van Os Lusíadas (1572) by die huidige St Helena-baai met die plaaslike bevolking. Die sosiale antropoloog op die tog, Fernao Veloso, begelei die plaaslike groep terug, maar moet na die skepe vlug as hulle hom begin aanval. Da Gama- 
hulle kom tot sy redding, maar Da Gama self word tydens die skermutseling met ' $n$ pyl in die been verwond (vgl. Gray 1979:19-21 se ooreenstemmende beskrywing en interpretasie van die voorval).

De Vries (1988:9) vind dit nodig om met die vierhonderdjarige herdenking van Dias se vaart om die Kaap in 1988 te vra: 'sou enige digter/dramaturg in 1988 'n hoorspel oor Dias skryf waarin met geen woord na dié eerste gewelddadige konfrontasie, dié eerste doodslag, verwys word nie?'. Hy (De Vries 1988:9) wys tereg daarop dat Dias (1952) binne 'n ander literêr paradigmatiese konteks inpas as wat toe en tans gangbaar is. In 1988 is dit 'van die letterkunde - met op sy beurt die veranderende aard en inhoude $-[\ldots]$ verwag $[\ldots]$ om 'n dergelike historiese feit nie te vermy nie'.

\section{Gevolgtrekking}

Hierdie bespreking bevestig die aanvanklike aanname dat daar ooreenkomste tussen N.P. van Wyk Louw se radiodrama Dias (1952) en veral kanto 5 van Luís Vaz de Camões se Os Lusíadas (1572) bestaan. Onderliggend aan die bevestiging is dat die representasie van Adamastor in Camões se Os Lusíadas (1572) met die matrose se ervaring in Dias (1952) van 'n storm tydens hul suidwaartse vaart om die Kaap ooreenstem. Adamastor se weergawe van hoe die gode hom as straf in Tafelberg verander het en van sy taak om te verhoed dat die Portugese rondom die Kaap van Storms vaar, versterk dié interpretasie. In Camões en in Louw se werke is die karakter Dias sy eerste slagoffer.

Die bespreking bevestig verder twee opvallende ooreenkomste wat uit dié interpretasie volg, naamlik dat beide tekste 'n allegoriese en nasionale aard vertoon. In Os Lusíadas (1572) slaan die allegoriese op Adamastor se sinnebeeldige aard en op die nasionale, selfs patriotiese, instelling van Da Gama se vertelling van die geskiedenis van Portugal aan die sjeik van Malindi. In Dias (1952) blyk die allegoriese uit die voorstelling van Dias as verteenwoordiger van elke mens en van sy reis as 'n lewensreis. Die matrose se ervaring van die Streek van die Suide sluit teen die agtergrond van hul Ptolemaïese wêreldbeeld daarby aan. Die dramaturg se Suid-Afrikaanse perspektief op die kus en aangrensende binneland tree na vore in sy verwysing na klipkruise wat op Suid-Afrikaanse grondgebied geplant is en uit die titelkarakter se verbondenheid aan die land as identiteitsruimte (vgl. Pedro se woorde by hul omdraaipunt).

Die ooreenkomste het egter verskillend ontstaan. By Camões is die oorsprong vanweë die dramaturg se lewensverloop hoofsaaklik biografies. By Louw hou die oorsprong van Dias (1952) met Douglas Fuchs se versoek verband dat Louw 'n radiodrama ter herdenking van die 25ste herdenking van die bestaan van radio in Natal sal skryf.

'n Verdere verskil tussen die tekste betrek die historiese verloop onderliggend aan elkeen. Camões het voortgegaan om, in Gray (1980:2) se woorde, die boegbeeld en embleem van Portugal se nasionale gees te word. Daarteenoor kenmerk revisionisme tans sommige literatore se interpretasies van Louw se dramas, wat Dias (1952) insluit.

\section{Erkenning Mededingende belange}

Die outeur verklaar hiermee dat hy geen finansiële of persoonlike verbintenis het met enige party wat hom nadelig of voordelig kon beïnloed het in die skryf van hierdie artikel nie.

\section{Literatuurverwysings}

Ames, G.J., 2009, Em Nome de Deus: The journal of the first voyage of Vasco da Gama to India, 1497-1499, Brill, Leiden. http://dx.doi.org/10.1163/ej.9789004176430.i-182

Antonissen, R., 1963, Kern en tooi: Kroniek van die Afrikaanse letterkunde, Nasou, Kaapstad.

Antonissen, R., 1973, Die Afrikaanse letterkunde van aanvang tot hede, Nasou, Kaapstad.

Camoëns, L., [1776] 1877, The Lusiad: Or, the discovery of India: An epic poem, in sacred-texts.com, transl. W.J. Mickle, 5 th rev. edn., viewed 05 April 2008, from http://www.sacred-texts.com/neu/lus/index.htm

Cattell, K., 2008, 'N.P. van Wyk Louw en die utopie van 'n nasionale letterkunde', ongepubliseerde D.Phil.-proefskrif, Universiteit van die Witwatersrand, Johannesburg.

Coetser, J.L., 1986, 'Die struktuur van die allegorie', Tydskrif vir Literatuurwetenskap 2(2), 29-40.

Degenaar, J., 1976a, 'Die politieke filosofie van N.P. van Wyk Louw I', Standpunte 121, 29(1), 21-34.

Degenaar, J., 1976b, 'Die politieke filosofie van N.P. van Wyk Louw II', Standpunte 122, 29(2), 53-62.

Degenaar, J., 1976c, 'Die politieke filosofie van N.P. van Wyk Louw III', Standpunte 123, 29(3), 34-45.

Dokumentesentrum, s.j., 'N.P. van Wyk Louw-versameling, 2.D.Di.1, Aantekeninge oor dramateks, Holograaf', J.S. Gericke-biblioteek, Universiteit van Stellenbosch, Stellenbosch.

De Kock, W.J., 1957, Portugese ontdekkers om die Kaap: Die Europese aanraking met Suidelike Afrika 1415-1600, A.A. Balkema, Kaapstad.

De Vries, A.H., 1988, 'Dias en Dias: 1488, 1952, 1988', Tydskrif vir Letterkunde 16(1), 6-9.

Fletcher, A., 1982, Allegory: The theory of a symbolic mode, Cornell University Press, Ithaca.

Gray, S., 1979, Southern African literature: An introduction, David Philip, Cape Town.

Gray, S., 1980, Camoens and the poetry of South Africa, Oppenheimer Institute for Portuguese Studies, Johannesburg.

Honig, E., 1982, Dark conceit: The making of allegory, Northwestern University Press, Evanston.

Jaritz, G., 2009, 'From the peripheries to the centres and back again: Visual culture and the edges of this world', in G. Jaritz \& J. Kreem (eds.), The edges of the medieval world, p. 2138, Central European University, Department of Medieval Studies, Budapest.

Le Roux, S.W. \& Ferreira, O.J.O., 2008, 'Camões in Afrikaans: Vertaling van die gedeelte uit Os Lusíadas wat oor die Suidpunt van Afrika handel', inl., vert. S.W. le Roux \& O.J.O. Ferreira, Tydskrif vir Geesteswetenskappe 48(1), 95-110.

Louw, N.P.V., 1975 [1952], Dias: 'n Hoorspel, 2de uitg., Tafelberg, Kaapstad.

Malan, R., 2010, s.v. 'allegorie', Literêre terme en teorieë, besigtig 09 Februarie 2014, by $\mathrm{http}: / /$ www.literaryterminology.com/index.php/categories/9-allegorie

Olivier, G., 1992, N.P. van Wyk Louw: Literatuur, filosofie, politiek, Human \& Rousseau, Kaapstad.

Olivier, G., 1998, 'N.P. van Wyk Louw (1906-1970)', in H.P. van Coller (red.), Perspektief en profiel: 'n Afrikaanse literatuurgeskiedenis, deel 1, bl. 615-635, Van Schaik, en profiel:
Pretoria.

Opperman, D.J., 1949, Joernaal van Jorik, Tafelberg, Kaapstad.

Renders, L., 2002, 'Die dramatiese werk van N.P. van Wyk Louw: Met volk-wees as inspirasie', LitNet, besigtig op 29 Mei 2013, by http://www.oulitnet.co.za/seminaar/ vanwyklouw.asp

Ricoeur, P., 1986, Lectures on ideology and utopia, intro. G.H. Taylor (ed.), Columbia University Press, New York.

Schutte, H.J., 1988, 'Verwerking van die geskiedenis in Dias deur N.P. van Wyk Louw: 'n Suid-Afrikaanse perspektief', Tydskrif vir Letterkunde 16(2), 39- 48.

Smith, M.V., 2011, 'Shades of Adamastor: The legacy of The Lusiads', in D. Attwell \& D. Attridge (eds.), The Cambridge history of South African literature, pp. 117-137, Cambridge Histories Online - Cambridge University Press, Cambridge.

Steyn, J.C., 1998a, Van Wyk Louw: 'n Lewensverhaal, deel 1, Tabelberg, Kaapstad.

Steyn, J.C., 1998b, Van Wyk Louw: 'n Lewensverhaal, deel II, Tabelberg, Kaapstad.

Van Heerden, E., 1978, Die digter as chromatometer: Aspekte van kleurgebruik in die poësie van N.P. van Wyk Louw, Randse Afrikaanse Universiteit, Johannesburg.

Van Rensburg, F.I.J., 1975, Swewende ewewig: Beskouings oor die werk van N.P. van Wyk Louw, deel II, Tafelberg, Kaapstad.

Welch, S.R., 1935, Europe's discovery of South Africa, Juta, Cape Town. 